\title{
Ritka etiológiájú fiatalkori szívinfarktus
}

\author{
Nagy Gábor Zoltán dr. ${ }^{1}$ - Gerges Gábor dr. ${ }^{1}$ - Csapó Kálmán dr. ${ }^{1}$ \\ Csengő Erika dr. ${ }^{1}$ - Minik Károly dr. ${ }^{2}$
}

\author{
Borsod-Abaúj-Zemplén Megyei Kórház és Egyetemi Oktatókórház, ${ }^{1}$ I. Belgyógyászat, Kardiológiai Osztály, \\ ${ }^{2}$ Patológiai Intézet, Miskolc
}

\begin{abstract}
A fiatal, 35 év alatti populációban a mellkasi fájdalom kórképe nem ritkaság, ugyanakkor ezek hátterében a tényleges akut coronariaszindróma lényegesen ritkább. Ennek ellenére coronariaelzáródás fiatalkorban is előfordul, s nem gyakori volta miatt könnyen diagnosztikus tévedéshez vezethet. A szerzők 19 éves fiatal nőbeteg esetét ismertetik, aki hirtelen rosszullét, mellkasi fájdalom miatt került felvételre a területileg illetékes kórház sürgősségi osztályára. Az első vizsgálatok során az EKG-n ST-szakasz-elevációt észleltek és - aortadissectiót gyanítva a panaszok hátterében - mellkas-komputertomográfiás vizsgálatot végeztek. A gyanú nem igazolódott, és a beteget a szerzók osztályára szállították. A primer coronariaintervenció során a főtörzs totális occlusióját észlelték. A sikeres revascularisatio ellenére a beteget a posztoperatív 2. napon asystolia következtében elveszítették. A kórbonctani lelet a főtörzs embolisatióját igazolta, nagy kiterjedésű következményes haemorrhagiás necrosissal a bal kamra szinte teljes területén. Az embolia forrását nem találták. A szerzők kiemelik, hogy a főtörzselzáródás tünetegyüttese fiatalkorban aortadissectióhoz, illetve masszív pulmonalis embolisatióhoz hasonló tüneteket okozhat, és diagnosztikai problémát vethet fel. Orv. Hetil., 2015, 156(25), 1020-1025.
\end{abstract}

Kulcsszavak: fiatal beteg, bal közös törzs, embolia, aortadissectio, pulmonalis embolia, differenciáldiagnózis

\section{Rare case of myocardial infarct in a young adult. Case report}

\begin{abstract}
Chest pain is not uncommon among young patients below the age of 35 years, however, it is rarely caused by acute coronary syndrome. The rarity of coronary artery occlusion in this population can easily lead to diagnostic mistakes. The authors present the case history of a 19 -year-old young female, who was admitted to the emergency department of a local hospital due to the sudden onset of chest pain and malaise. ST-segment elevation was seen on the electrocardiogram raising the possibility of aortic dissection, therefore, emergency thoracic computed tomographic scan was performed. This proved to be negative and the patient was transferred to the coronary care unit. Urgent coronarography was carried out, which revealed the total occlusion of the left main coronary artery. The occluded artery was successfully opened with percutaneous coronary intervention, but despite revascularisation the patient died on the second postoperative day due to asystole. Autopsy revealed thrombotic embolization of the left main artery with consequent extensive haemorrhagic necrosis, involving almost the whole left ventricle. The source of embolization was not found. The authors note that left coronary artery occlusion in young patients can be a diagnostic challenge, because symptoms can be mistaken with aortic dissection or pulmonary embolism.
\end{abstract}

Keywords: young patient, left main coronary artery, embolism, aortic dissection, pulmonary embolization, differential diagnosis

Nagy, G. Z., Gerges, G., Csapó, K., Csengö, E., Minik, K. [Rare case of myocardial infarct in a young adult. Case report]. Orv. Hetil., 2015, 156(25), 1020-1025.

(Beérkezett: 2015. március 2.; elfogadva: 2015. április 16.)

\section{Rövidítések}

atm = atmoszféra; BMS = (bare metal stent $)$ „egyszerü” fémstent; $\mathrm{CK}$ = kreatinkináz; $\mathrm{CKMB}=$ szívizom-specifikus kreatinkináz; $\mathrm{CT}=$ komputertomográfia; $\mathrm{Cx}=$ arteria circumflexa körbefutó ág; DES = (drug eluting stent) gyógyszerkibocsátó stent; $\mathrm{EF}=$ ejekciós frakció; $\mathrm{EKG}=$ elektrokardiogram;
$\mathrm{G} / \mathrm{l}=$ giga $\left(10^{9}\right) /$ liter $;$ Hgmm $=$ higanymilliméter LAD $=($ left anterior descendens) bal elülső leszálló ág; $\mathrm{mm}=$ milliméter; $\mathrm{ng} / \mathrm{ml}=$ nanogramm $/$ milliliter; NSTEMI $=$ nem ST-elevációs myocardialis infarctus; STEMI = ST-elevációs myocardialis infarctus 
A fiatal, 35 év alatti populációban a mellkasi fájdalom kórképe nem ritkaság, ugyanakkor ezek hátterében a tényleges akut coronariaszindróma lényegesen ritkább. Ennek ellenére coronariaelzáródás fiatalkorban is előfordul, s nem gyakori volta miatt könnyen diagnosztikus tévedéshez vezethet.

\section{Esetismertetés}

A 19 éves nóbetegünk anamnézisében hypertonia, diabetes mellitus vagy egyéb jelentős megbetegedés nem szerepelt. Családi anamnézisről lényeges adat nem állt rendelkezésünkre. Jelen megbetegedése előtt panaszai nem voltak. Felvételét megelőzően az iskolában hirtelen rosszulléte alakult ki. Összeesett, mellkasi fájdalma volt, egy alkalommal hányt. Mellkasi fájdalom miatt a területileg illetékes sürgősségi osztályra szállították.

Az EKG-képen (1. ábra) atípusos jobbszár-blokk jellegű alapgörbe mellett aVR- és aVL-elvezetésekben STeleváció, II-III. avF-ben 5-8 mm-es ST-depresszió ábrázolódott, kissé kiszélesedett QRS-komplexusok mellett. A tünetek hátterében pulmonalis embolia, illetve aortadissectio merült fel elsősorban, emiatt sürgősséggel mellkasi CT történt. A CT mindkét kórképet kizárta, pulmonalis oedema ábrázolódott. A CT-vizsgálatot követően tüdőoedema, akut balszívfél-elégtelenség alakult ki, amely miatt intubálás történt, gépi lélegeztetést kezdtek. Egy alkalommal kamrafibrilláció lépett fel, amely miatt elektromos defibrillációra volt szükség. Tájékozódó echokardiográfia történt, ami septalis hypokinesist muta- tott. A fentiek figyelembevételével, az EKG-kép alapján, akut anterior myocardialis infarctust véleményeztek. Thrombolysis nem történt, primer percutan coronariaintervenció céljából a beteget osztályunkra szállították. Szállítás előtt propofolszedáció, diuretikum és $5000 \mathrm{E}$ nátrium-heparin medikációban részesült.

A tünetek fellépésétől kezdődően mintegy 3 órás időablakkal vettük fel osztályunkra. Érkezéskor 100/60 Hgmm vérnyomásértéket, 96/min szívfrekvenciát detektáltunk, fizikális státusában érdemi eltérés nem mutatkozott. A felvételkor készített echokardiográfia kiterjedt anterior, lateralis, septalis falmozgászavart mutatott jelentősen csökkent (ejekciós frakció 34\%) bal kamrai szisztolés funkció mellett.

Azonnal koronarográfiát szerveztünk. A koronarográfia jobb femoralis behatolásból történt. A domináns jobb koszorúér épnek bizonyult. A bal ágrendszer első töltésénél már nyilvánvaló volt a bal közös törzs elzáródása (2. ábra). Azonnali percutan coronariaintervenció (PCI) mellett döntöttünk. Vezetődrótot juttattunk le az elzáródáson keresztül a LAD irányába. Már a drót levezetésénél feltünt, hogy az elzáródás konzisztenciája eltér a „szokványos” thromboticus elzáródásoktól. Intracoronariás szívókatéterrel thrombuseltávolítást kíséreltünk meg, amely nem volt eredményes. Ezt követően 1,5×15 mm-es ballont vezettünk sikeresen az elzáródásba és több alkalommal 15-22 atm nyomással igyekeztünk az áramlást megindítani. Ez csak részlegesen volt sikeres, nagyobb ballonnal próbálkozva sem tudunk jobb eredményt elérni (3. ábra).

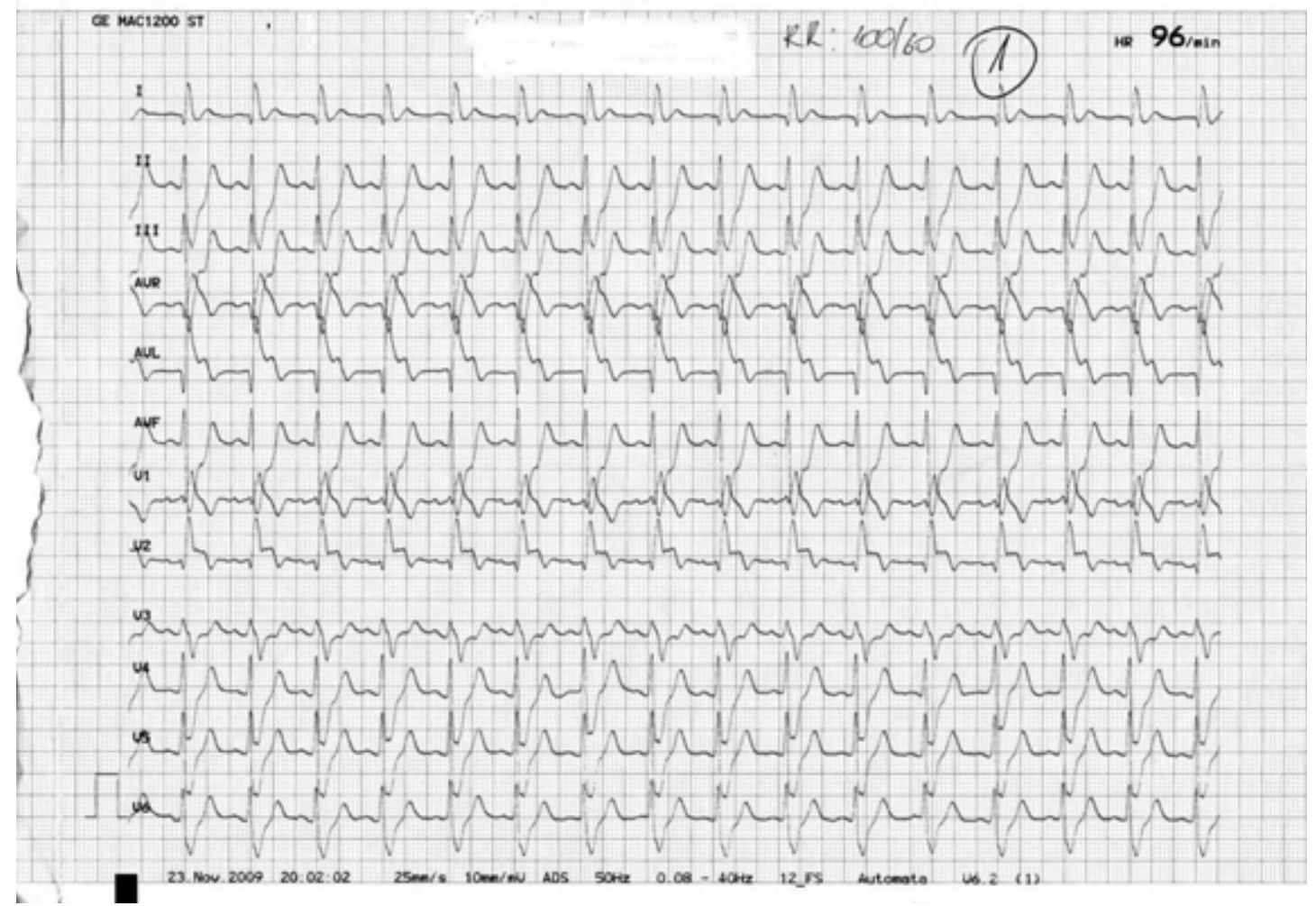

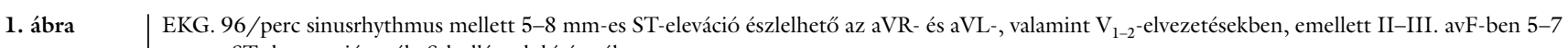
mm-es ST-depresszió, mély S-hullámok kíséretében 


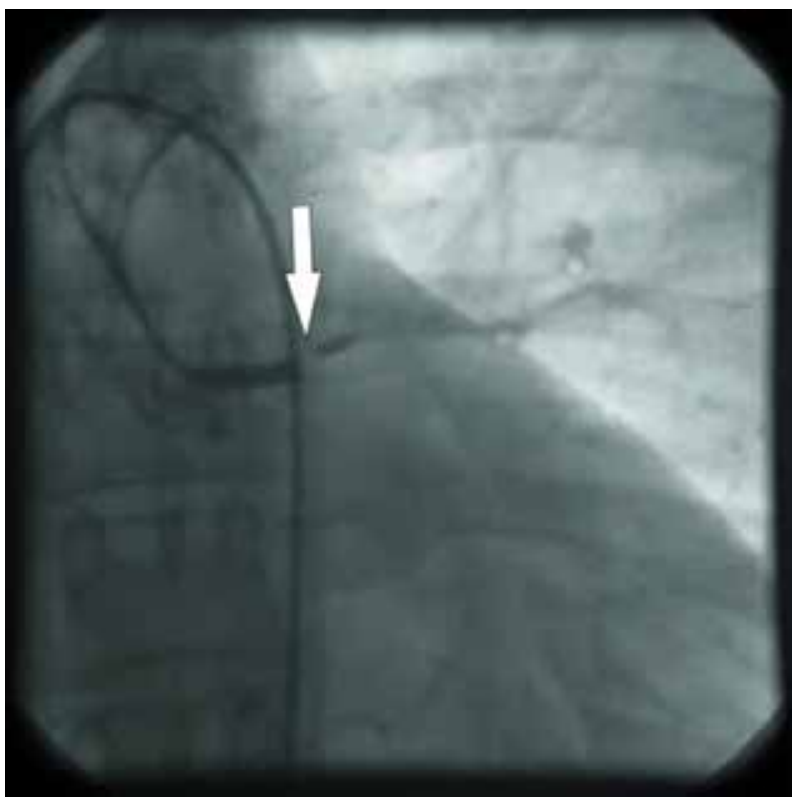

2. ábra

Bal koszorúér angiogram. A nyíllal jelölt helyen látható a ba közös törzs elzáródása, az elzáródás mögött rövid szakaszon az elülső leszálló ág kezdeti szakasza ábrázolódik

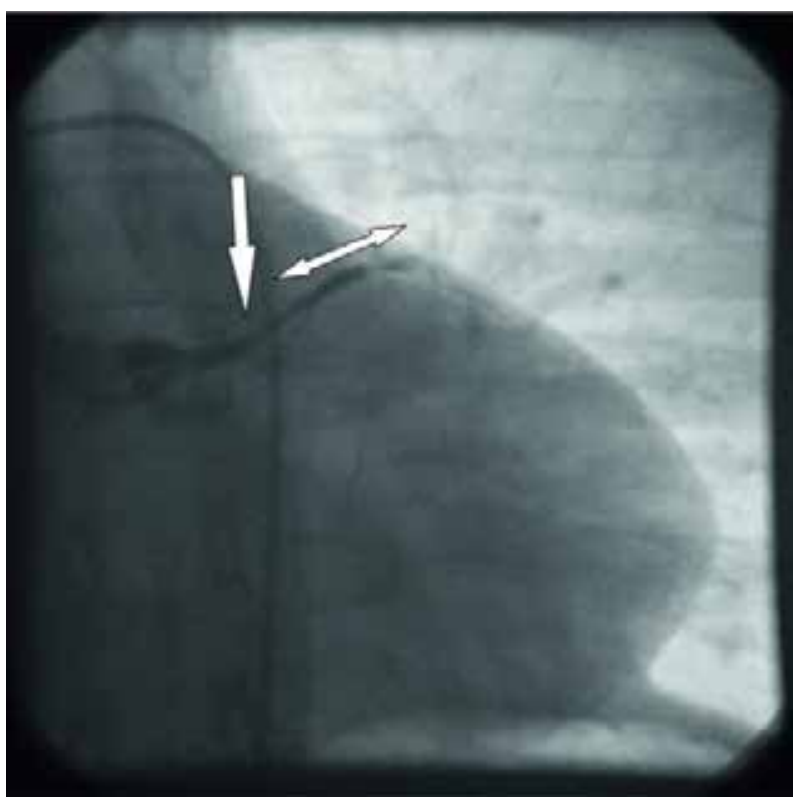

3. ábra

LAD részleges megnyílása. A nyíllal jelölt elzáródási hely mögött, a kettős nyíllal jelzett szakaszon feltűnik az elülső leszálló ág, de telődése csak részleges

Ekkor már felmerült a coronariaembolisatio lehetősége. Mivel a ballonos tágítás csak részleges eredménnyel járt, stentimplantáció mellett döntöttünk, és $3 \times 18 \mathrm{~mm}$ es DES-t pozicionáltunk a fötörzsből a LAD irányába. A stentimplantációt követően a LAD-ban megindult az anterográd áramlás (4. ábra).

A perzisztáló hypotonia miatt $(70-80 \mathrm{Hgmm}$ szisztol- és vérnyomás) bal oldali arteria femoralis behatolásból $7 \times 40 \mathrm{ml}$-es intraaorticus ballonpumpát vezettünk

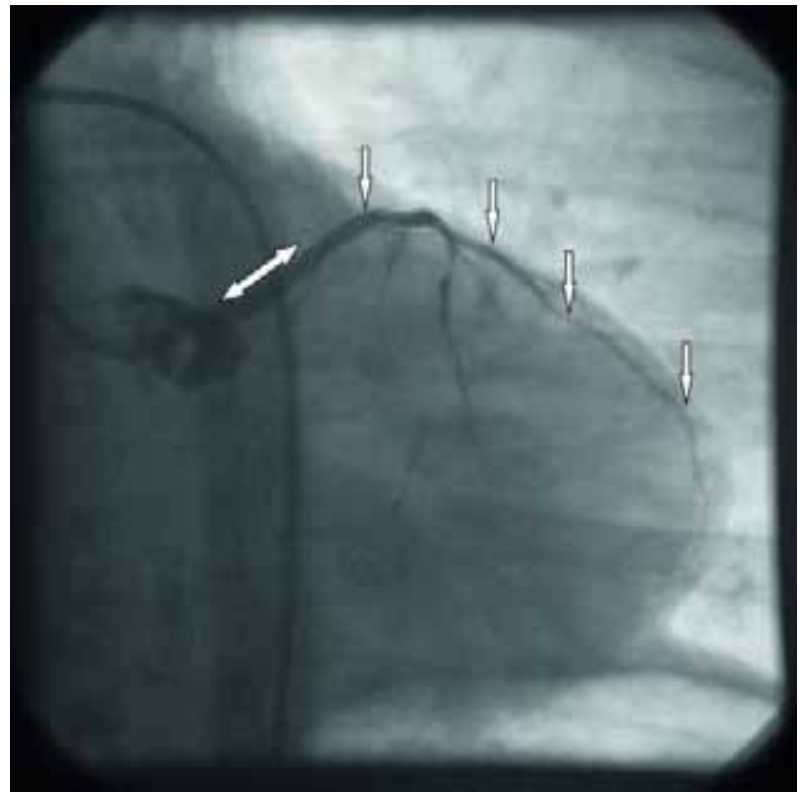

4. ábra

Stent a főtörzsben. A kettős nyíl a főtörzsbe helyezett stentet jelöli, mögötte a kisebb nyilak a szívcsúcsig követhető LAD-ot mutatják

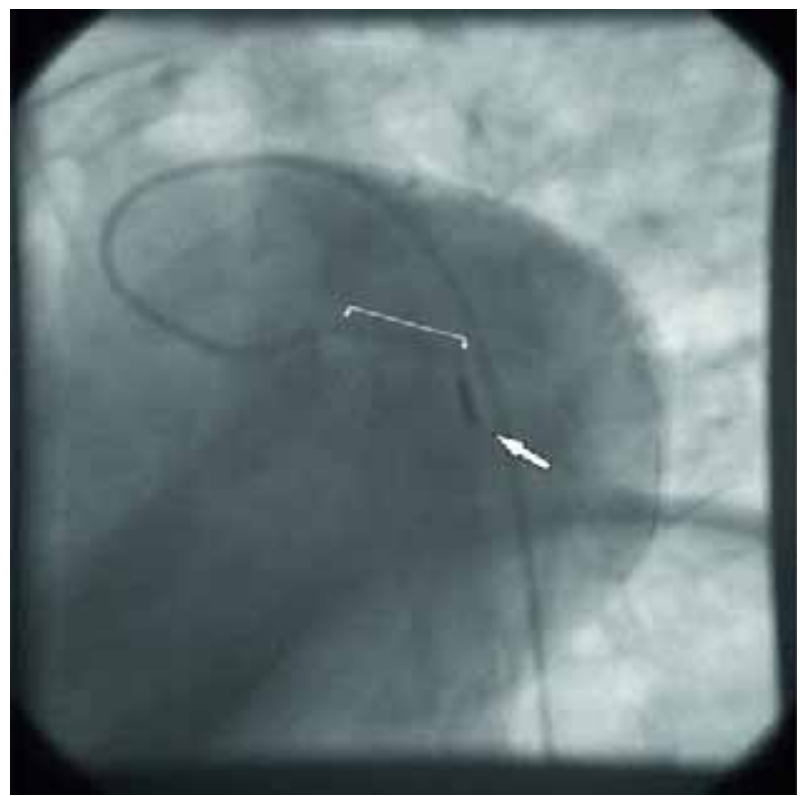

5. ábra

Stentimplantáció az arteria circumflexa kezdeti szakaszába. A vékony nyíl a stentet jelöli, a kép közepén a vastag nyíl az intraaorticus ballonpumpa markerére mutat

be keringéstámogatás céljából [1]. Ennek segítségével 95-100 Hgmm-es augmentált szisztolés vérnyomásértékeket tudtunk stabilan elérni. Ezt követően az arteria circumflexa irányába újabb vezetődrótot sikerült lejuttatnunk a fötörzs-LAD-stent oldalnyílásain keresztül, és itt is próbálkoztunk ballonos megnyitással. Ez ismét csak részlegesen volt sikeres, és rövid időn belül az elért csekély anterográd áramlás megszűnt. Úgy döntöttünk, ide is stentimplantátumot helyezünk be $(2,75 \times 18 \mathrm{~mm}$, 


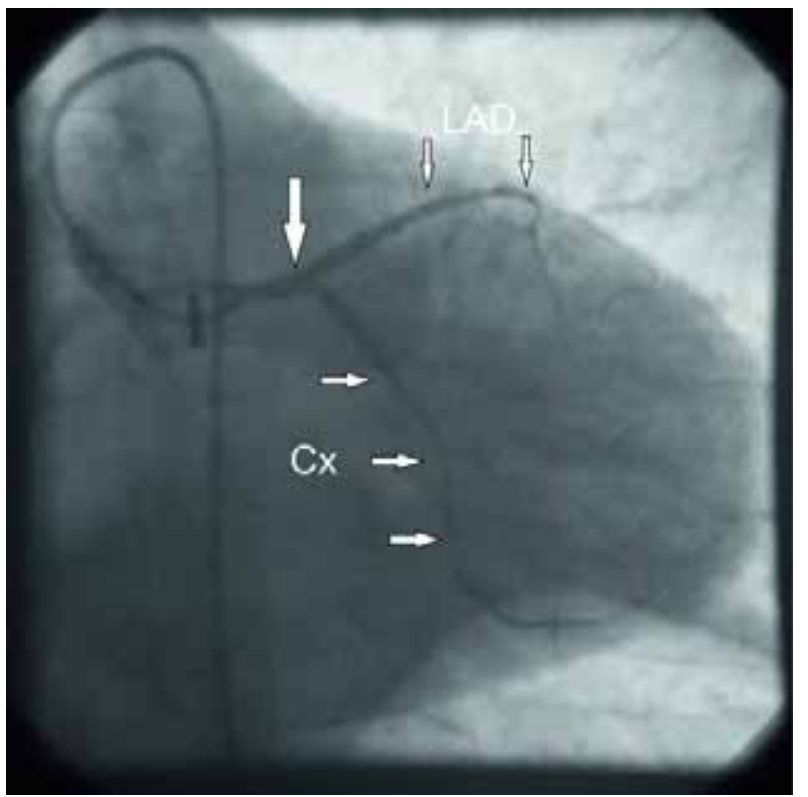

6. ábra

Végeredmény. A korábbi főtörzselzáródást okozó thrombus már nem látható, a kontrasztanyag-áramlás mind a LAD-ban, mind a circumflexában kielégítő. A vastag nyíl a korábbi elzáródás helyét jelöli

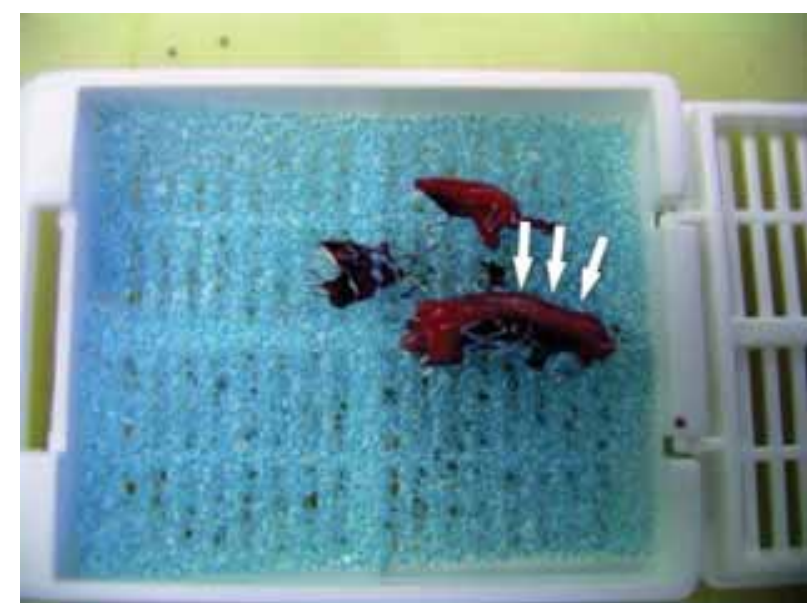

7. ábra

Kórbonctani anyag: a kipreparált stentek. Közelített fényképen a két stent látható, az expandált stentek külső felszínét a tömör embolus hengerpalástszerúen borítja

BMS) (5. ábra). Szimultán ballontágítást követően („final kissing”) jó áramlást detektáltunk mind a LAD, mind a CX felé (6. ábra).

A sikeres intervenciót követően a beteget intenzív részlegünkön obszerváltuk tovább. Folyamatos gépi lélegeztetés és intraaorticus ballonpumpa mellett keringéstámogatás alkalmazására volt szükség (dobutamin, noradrenalin). A sürgősséggel elküldött első laboratóriumi eredmények 1,5 $\mathrm{ng} / \mathrm{ml}$ troponin I-t (normális érték $1 \mathrm{ng} / \mathrm{ml}$ alatt), enyhén emelkedett kreatinkinázt (CK), illetve szívizom-specifikus kreatinkinázt (CKMB) mutattak. A fehérvérsejtszám $18 \mathrm{G} / 1$ volt. Jelentős eltérések mutatkoztak viszont a másnap reggeli ( 8 órával későbbi) laboratóriumi paraméterekben, ekkor már - nem megle-

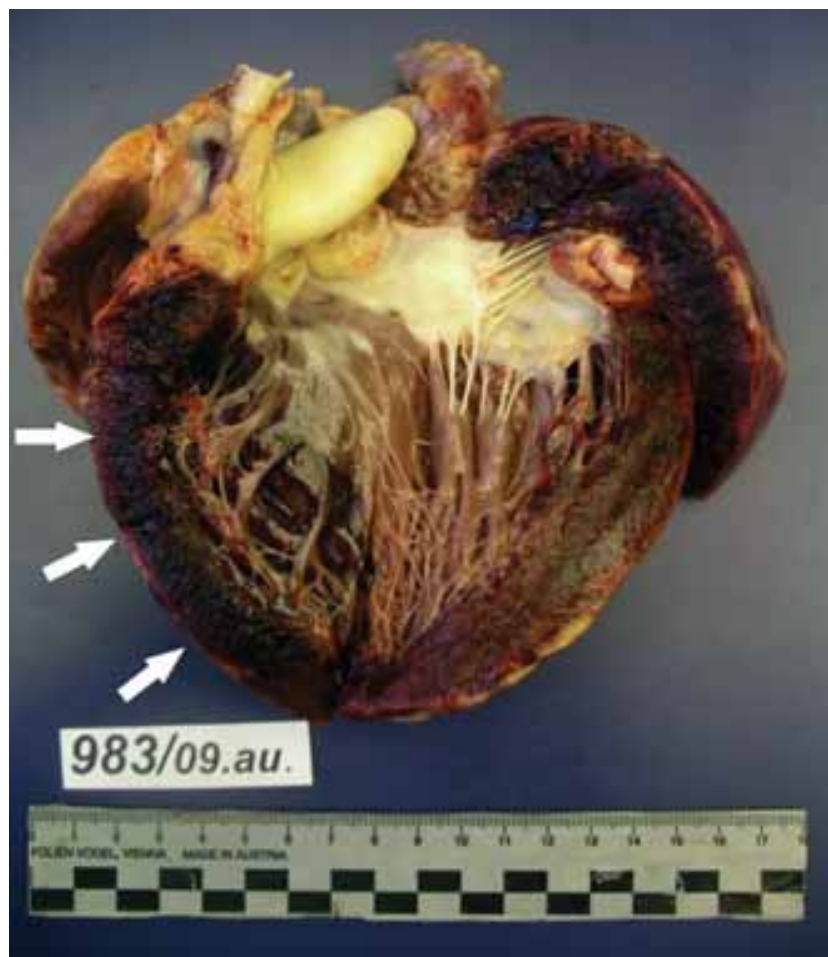

8. ábra

Bal kamrai necrosis. A felvágott bal kamra elülső falán sötétvörös-feketés színnel tűnik fel a necroticus terület, amelyet nyilak jelölnek

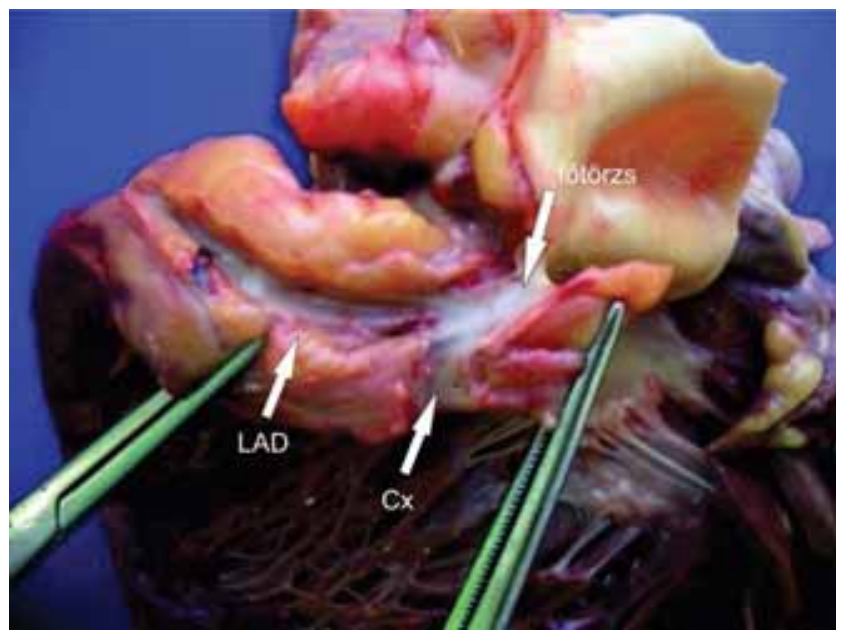

9. ábra

| Ép fötörzs és LAD-Cx oszlás

pő módon - $100 \mathrm{ng} / \mathrm{ml}$ feletti troponin- és $12000 \mathrm{U} / \mathrm{l}$ CK-értékek mutatták a súlyos myocardiumkárosodást.

A továbbiakban mechanikus és gyógyszeres kombinált keringéstámogatás mellett is perzisztáló hypotonia uralta a kórképet, majd a beteg kezelésének második napján magas láz jelentkezett. A korai laboratóriumi eredmények nem mutattak bakteriális infekcióra utaló jeleket, ettől függetlenül kombinált antibiotikus terápiát indítottunk. Magas láza ennek ellenére mind fizikális, mind gyógyszeres lázcsillapítás mellett befolyásolhatatlan volt. A fiatalkori STEMI-t figyelembe véve felmerült immu- 
nológiai kórkép gyanúja, ez irányú vizsgálatokat indítani szándékoztunk, de a felvételét követő 36. órában a betegnél bradycadia, asystolia lépett fel. A reanimáció sikertelen volt, betegünket elveszítettük.

A kórboncolás a fötörzsbe és a körbefutó ágba beültetett stentek körül 0,5-1 mm vastagságban szürkésfehér, thromboemboliás anyagot igazolt, ami szövettanilag szeptikus embolusnak bizonyult (7. ábra). A bal kamra septalis, anterior és lateralis falának megfelelően, a papillaris izmot is érintve, a szívizom teljes vastagságának megfelelően vérzéses necrosis mutatkozott (8. ábra). A coronariákon sérülés, plakk, plakkruptura nem volt található, az endothel a fơtörzs-körbefutó ág szögletében is épnek mutatkozott (9. ábra).

$\mathrm{Az}$ igen részletes sectio során egyértelmú emboliaforrást nem sikerült találni. Felmerült endocarditis lehetősége, de ezt sem a klinikum, sem az ép szívbelhártyát és billentyứket mutató kórboncolás nem igazolta.

$\mathrm{Az}$ elvégzett vírusszerológiai vizsgálatokkal virális infekciót nem sikerült kimutatni. Az immunológiai szakvizsgálat során felmerült immunológiai kórképek (antifoszfolipid-szindróma, vasculitis) laboratóriumi diagnosztikáját már nem állt módunkban elvégezni.

\section{Megbeszélés}

A szív- és érrendszeri megbetegedések kockázatával, veszélyeivel szinte mindenki tisztában van. Sajnos, ezek a problémák már fiatalkorban, 35 év alatt is előfordulnak. A fiatalkori szívinfarktus kockázati tényezői között szerepelhet a stresszes életmód, mértéktelen koffeinbevitel, energiaitalok túlzott fogyasztása, kábítószer-fogyasztás, dohányzás, valamint genetikai hajlam, amely családi halmozódásban nyilvánulhat meg.

Osztályunkon a 2008 és 2014 közötti időszakban 162 esetben találkoztunk 35 éves életkor alatt előforduló akut coronariaszindrómával (STEMI, NSTEMI, instabil angina), ami az összes akut coronariaszindróma 2,1\%-a. Ez a gyakoriság az irodalmi adatoknál ( 0,7\%) [2] kissé magasabb, amit régiónkban életvitelbeli sajátosságok magyarázhatnak.

A fiatalkori infarktusok két csoportba oszthatók, attól függően, hogy az arterioscleroticus folyamat érinti-e a coronariákat vagy nem. Normális coronariafal esetén az elzáródás okaként leginkább spasmus vagy embolia jön szóba. A coronariák kóros elváltozását és következményes myocardialis infarctust akcelerált arteriosclerosis (familiáris hyperlipidaemiák), spontán dissectio, aneurysma, ectasia, illetve kóros coronariaeredés hozhatja létre.

A coronaria embolisatiója önmagában sem gyakori kórkép, irodalmi adatok az összes STEMI körülbelül 5\%ának adják meg, ezen belül speciálisan a fötörzs embolisatiójára, illetve fiatalkori előfordulására nem találtunk konkrét adatot. Maga a fótörzs embolisatiója leggyakrabban mübillentyú-implantációt követően fordul elő, nem kellő antikoagulálás következtében. Az esetünkhöz hasonló szeptikus embolisatio leginkább endocarditis következménye szokott lenni [3, 4, 5, 6, 7]. Emellett fiatalkori akut coronariaszindrómában hazánkban is egyre inkább realitás lehet a kokainabúzus következtében létrejött, fötörzset is érintő coronariaspasmus [8].

Differenciáldiagnosztikai szempontból az aortadissectio, illetve a masszív pulmonalis embolia kizárása szükséges, ezek tünetei az akut coronariaszindrómához igen hasonlóak lehetnek [2]. Fiatalkori előfordulásuk is gyakoribb, az aortadissectiós esetek mintegy 7\%-a [9], a pulmonalis embolia 20-22\%-a fiatalabb korban alakul ki, így ezekre kell elsősorban gondolni. Az EKG és laboratóriumi eredmények nem specifikusak, mindhárom kórképben diffúz, néha bizarr eltérések előfordulnak. A diagnózist ebben az esetben a sürgősséggel elvégzett mellkasi CT-vizsgálat segítheti, ami egyértelmúen megerősítheti, illetve kizárhatja mind az aortadissectiót, mind a pulmonalis emboliát $[10,11]$. A mellkas-CT-vizsgálat előtérbe helyezését mindenképpen indokolja az, hogy invazív kardiológiai diagnosztika aortadissectio esetén ellenjavallt.

\section{Következtetések}

Fiatalkorban a fötörzs-embolisatio ritka, de igen súlyos, gyakran minden beavatkozás ellenére fatális kórkép, amelynek mind a diagnosztikája, mind a megoldása számos nehézséget jelent. Megoldásában a teammunka, a szakmák közötti együttmúködés (oxiológia, radiológia, kardiológia, intenzív terápia) döntő fontosságú.

Anyagi támogatás: A közlemény megírása anyagi támogatásban nem részesült.

Szerzői munkamegosztás: N. G. Z.: Esetleírás, kézirat szövegezése, intervenciós felvételek. G. G., Cs. E.: Intenzív beteganyag rendszerezése, kézirat szövegezése, irodalmi hivatkozások. Cs. K.: Kézirat szövegezése, irodalmi hivatkozások. M. K.: Patológiai anyag szerkesztése. A cikk végleges változatát valamennyi szerző elolvasta és jóváhagyta.

Érdekeltségek: A szerzőknek nincsenek érdekeltségeik.

\section{Irodalom}

[1] Thiele, H., Zeymer, U., Neumann, F. J., et al.: Intra-aortic balloon counterpulsation in acute myocardial infarction complicated by cardiogenic shock (IABP-SHOCK II): final 12 month results of a randomised, open-label trial. Lancet, 2013, 382(9905), 16381645 .

[2] Windecker, S., Kolh, P., Alfonso, F., et al.: 2014 ESC/EACTS guidelines on myocardial revascularization. Eur. Heart J., 2014, 35(37), 2541-2619.

[3] Prizel, K. R., Hutchins, G. M., Bulkey, B. H.: Coronary artery embolism and myocardial infarction: a clinicopathologic study of 55 patients. Ann. Intern. Med., 1978, 88(2), 155-161.

[4] Hall, M. R., Richards, W. C.: Coronary artery embolism. Br. Heart J., 1961, 23, 103-106. 
[5] Davies, M. J., Thomas, A.: Thrombosis and acute coronary-artery lesions in sudden cardiac ischemic death. N. Engl. J. Med., 1984, 310(18), 1137-1140.

[6] Roberts, W. C., Buja, L. M.: The frequency and significance of coronary arterial thrombi and other observations in fatal acute myocardial infarction. A study of 107 necropsy patients. Am. J. Med., 1972, 52(4), 425-443.

[7] Warren, J. R.: Coronary artery thrombosis. JAMA, 1975, $231(11), 1135$

[8] Finkel, J. B., Marhefka, G. D.: Rethinking cocaine-associated chest pain and acute coronary syndromes. Mayo Clinic Proc., 2011, 86(12), 1198-1207.

[9] Januzzi, J. L., Isselbacher, E. M., Fattori, R., et al.: Characterizing the young patient with aortic dissection: results from the International Registry of Aortic Dissection (IRAD). J. Am. Coll. Cardiol., 2004, 43(4), 665-669.
[10] Schoenenberger, A. W., Radovanovic, D., Stauffer, J. C., et al.: Acute coronary syndromes in young patients: presentation, treatment and outcome. Int. J. Cardiol., 2011, 148(3), 300304.

[11] Konstantinides, S. V., Torbicki, A., Agnelli, G., et al.: 2014 ESC Guidelines on the diagnosis and management of acute pulmonary embolism. Eur. Heart J., 2014, 35(43), 3033-3073.

(Nagy Gábor Zoltán dr., Miskolc, Szentpéteri kapu 72-76., 3526 e-mail: gafi@freemail.hu)

\section{NÉMETORSZÁGI MUNKA}

Némettudással rendelkező ápoló és gondozó hölgyeket / urakat keresünk németországi munkára.

Hivatalos munka, kiváló fizetéssel, illetve soförszolgálattal.

Jelentkezni lehet:

Fényképes önéletrajzzal az otthongondoskodas@gmail.com email címen, vagy a +36-30-205-67-83-as telefonszámon. 